\title{
Arachnoid cysts in the middle cranial fossa: cause and treatment of progressive and non-progressive symptoms
}

\author{
FGA VAN DER MECHÉ, ${ }^{*}$ R BRAAKMAN $\dagger$ \\ From the Departments of Neurology* and Neurosurgeryt, University Hospital Rotterdam-Dijkzigt, \\ Rotterdam, the Netherlands
}

SUMMARY Ten consecutive patients with arachnoid cysts in the middle cranial fossa, diagnosed by CT, were studied. They were divided into three clinical groups: (1) four patients with progressive symptoms caused by secondary bleeding, (2) five patients with non-progressive symptoms of headache or epilepsy, and (3) one asymptomatic patient. The nine symptomatic patients were operated upon and eight showed clinical improvement. Measurements of the CT scans revealed equal brain volumes on the affected and normal sides, refuting the hypothesis that the cyst is caused by agenesis of the temporal lobe. The hemicranium on the affected side was larger, accommodating both the cyst and a normal brain volume. The progressive symptoms after bleeding were caused by brain shift and increased CSF pressure. The cause of the non-progressive symptoms has not yet been established: two mechanisms are suggested: (1) expansion of the cyst accompanied by compression of surrounding structures, and (2) disturbed CSF dynamics without increased intracystic pressure. Removal of the membranes of the cyst with an opening to the basal cisterns should resolve both problems. After surgery a residual cyst may remain.

Arachnoid cysts in the middle cranial fossa are usually considered to be developmental in nature. They seem to occur predominantly in children and adolescents, especially males, and more often on the left than on the right side. ${ }^{1}$ Temporal lobe agenesis syndrome is another name given to this condition, because during surgery it was discovered that the temporal lobe was absent or only partly developed. ${ }^{1}$

In the past, patients presented with either asymptomatic bulging of the head or with progressive symptoms, suggestive of a space-occupying lesion, usually caused by a secondary subdural bleeding. Many cases, however, remained undetected as revealed by an unsuspected incidence of 5 per 1000 in a systematic necropsy study. ${ }^{2}$ As a result of increasing availability of CT, arachnoid cysts are now more frequently diagnosed in relation to headache and epilepsy. If the association with these non-progressive conditions is not coincidental, symptoms might

Address for reprint requests: FGA van der Meché, University Hospital Rotterdam-Dijkzigt, 40 dr. Molewaterplein, 3015 GD Rotterdam, the Netherlands.

Received 10 April 1983

Accepted 2 June 1983 be caused by (1) a space-occupying effect with pressure on surrounding structures, (2) a change in CSF dynamics, (3) agenesis or dysgenesis of the temporal lobe, especially in the case of epilepsy.

If the cause is identified, then the appropriate therapy can be applied: that is decompression by cyst drainage to the peritoneal cavity or right cardiac atrium, or regulation of CSF flow by membranectomy and opening of the suprachiasmatic cisterns, or no surgical treatment at all if epilepsy is caused by dysgenesis of the temporal lobe.

In a first attempt to solve this problem we studied retrospectively ten consecutive patients diagnosed by CT. They were divided into groups according to their symptoms: (1) progressive symptoms defined as headache combined with nausea, vomiting, diplopia or papilloedema suggestive of raised intracranial pressure, and (2) non-progressive symptoms: headache or epilepsy.

\section{Patients and methods}

Between June 1977 and August 1981, an arachnoid cyst in the middle cranial fossa was diagnosed in 10 patients by CT. Nine patients were surgically treated; one patient was asymptomatic. Six patients were male; in seven cases the cyst was located on the left side; the median age was 12.5 
Table 1

\begin{tabular}{|c|c|c|c|c|c|c|c|c|}
\hline \multicolumn{4}{|c|}{$\overline{\text { Clinical data }}$} & \multicolumn{3}{|c|}{$C T$ scan data } & \multicolumn{2}{|l|}{ Follow-up } \\
\hline Ptno. & Sex & $\begin{array}{l}\text { Age } \\
\text { (yr) }\end{array}$ & Symptoms (duration) & $\begin{array}{l}\text { Cist size } \\
\left(\mathrm{cm}^{3}\right)\end{array}$ & Bleeding & $\begin{array}{l}\text { Midline } \\
\text { shift }\end{array}$ & $\begin{array}{l}\text { Duration } \\
\text { (months) }\end{array}$ & Results \\
\hline \multicolumn{9}{|c|}{ Patients with non-progressive symptoms } \\
\hline 1 & $\mathrm{~m}$ & 30 & $\begin{array}{l}\text { headache ( } 6 \text { months }) \\
\text { epilepsy ( } 1 \mathrm{wk})\end{array}$ & 3 & - & - & 6 & $\begin{array}{l}\text { free of symptoms } \\
\text { (no medication) }\end{array}$ \\
\hline 2 & $\mathrm{f}$ & 9 & $\begin{array}{l}\text { epilepsy ( } 6 \text { months) (numerous } \\
\text { generalised convulsions) }\end{array}$ & 10 & - & - & 9 & $\begin{array}{l}\text { very much improved } \\
\text { only } 1 \text { focal fit with } \\
\text { medication, as before }\end{array}$ \\
\hline 3 & $\mathrm{~m}$ & 37 & headache ( $>4$ yrs) & 22 & - & - & 21 & unchanged \\
\hline 4 & $\mathrm{~m}$ & 9 & $\begin{array}{l}\text { headache (6 yrs) } \\
\text { epilepsy ( } 1 \text { month })\end{array}$ & 31 & - & - & 54 & $\begin{array}{l}\text { free of headache } \\
\text { fits from a focus } \\
\text { contralateral to the cust }\end{array}$ \\
\hline 5 & $\mathrm{~m}$ & 4 & headache during walking (months) & 29 & - & + & 16 & $\begin{array}{l}\text { free of symptoms } \\
\text { development accelerrated? }\end{array}$ \\
\hline \multicolumn{9}{|c|}{ Patients with progressive symptoms } \\
\hline 6 & $\mathrm{~m}$ & 16 & $\begin{array}{l}\text { headache, nausea } \\
\text { vomiting, apathy ( } 2 \mathrm{wks})\end{array}$ & 63 & $\begin{array}{l}\text { subdural } \\
\text { haematoma }\end{array}$ & + & 16 & free of symptoms \\
\hline 7 & $\mathrm{~m}$ & 7 & $\begin{array}{l}\text { headache, diplopia } \\
\text { apathy, papilloedema ( } 3 \text { months) }\end{array}$ & 28 & $\begin{array}{l}\text { subdural } \\
\text { haematoma }\end{array}$ & + & 24 & free of symptoms \\
\hline 8 & $\mathrm{f}$ & 10 & $\begin{array}{l}\text { headache. nausea } \\
\text { vomiting, apathy ( } 1 \mathrm{mnth})\end{array}$ & 182 & $\begin{array}{l}\text { subdural } \\
\text { haematoma }\end{array}$ & + & 18 & free of symptoms \\
\hline 9 & $\mathrm{f}$ & 15 & $\begin{array}{l}\text { headache, nausea } \\
\text { vomiting. papilloedema ( } 1 \mathrm{mnth})\end{array}$ & 118 & $\begin{array}{l}\text { intracystic } \\
\text { haematoma }\end{array}$ & + & 6 & free of symptoms \\
\hline
\end{tabular}

Patient without symptoms

10 f 24 - 46

years (range 4 to 37 years). These figures are in accordance with those in the literature. ${ }^{34}$ Table 1 presents further details.

The operation consisted of removal of the outer membrane of the cyst and opening the inner membrane to create a connection with the suprachiasmatic cisterns. Histologynot performed in patients 2 and 5-showed arachnoid membranes in all others. At the end of 1981 all patients were seen by the first author. They were interviewed following a standard protocol and examined in detail for any minor focal deficit

\section{CT scan measurements}

In order to confirm or disprove the hypothesis of agenesis of brain tissue, the volumes of the left and right hemispheres were compared. To avoid measuring temporary volume changes, for example, those caused by secondary bleeding, a postoperative CT scan obtained at the time of follow-up was used. Two procedures were followed: (1) direct volume measurement, and (2) measurement of the skull "radius" as an indirect method. For direct volume measurements, only the scans with three or more slices above the lateral ventricles were used, in order to include as much brain tissue as possible. The scan of patient 1 , with the smallest cyst, was accordingly excluded. Tissue of the brain-stem and the cerebellum was excluded if it could be clearly distinguished on both sides. All scans were analysed by redrawing on paper the cyst and brain tissue from both sides. Subsequently the pieces of paper were cut out, weighed and their weights compared with the weight of a standard surface area. The weight of re-drawn and cut standard surface areas of $100 \mathrm{~cm}^{2}$ showed a variation of $<1 \%(\mathrm{n}=5)$. Knowing the thickness of the CT slice the volume could be calculated from these surface areas. The scan of patient 8 could be measured with an off-line computer-assisted CT scan analyser (Philips). The manual analysis of this patient differed by only $3 \%$ from the computer-assisted analysis (see results). The second, indirect method assumes an increase in skull diameter on the affected side compared with the normal side, if it has to contain both the cyst and the normal volume of brain tissue. Therefore, the skull "radius" was measured on both sides at the level of the pineal gland perpendicular to the midline.

\section{Results}

Nine patients were symptomatic. Four patients presented with progressive symptoms related to raised CSF pressure or brain shift (patients 6, 7, 8,9). They developed headache combined with nausea, vomiting, double vision or general malaise, all after minor trauma. All had a secondary bleeding: in three this was due to a subdural haematoma, and in one an intracystic bleeding. In retrospect, three of the four patients had at an earlier stage complained of nonprogressive symptoms: headache, general malaise and deteriorating academic performance. After surgery all patients were free from symptoms.

Five patients presented with non-progressive symptoms. Four of them had complained of headache for months (patients 1,5) or even years (patients $3,4)$. In patient no 4 only, was this related to minor trauma six years previously. In three of them, the pain was not localised; in the fourth (patient 3 ) the pain was usually on the side of the cyst, but occasionally contralateral. He was the only patient who did not benefit from the operation. None of these patients showed signs of haemorrhage at operation nor on histological examination of the membrane. Three patients suffered from epilepsy (patients 1, 2, 4; for patient 2 it was the only 


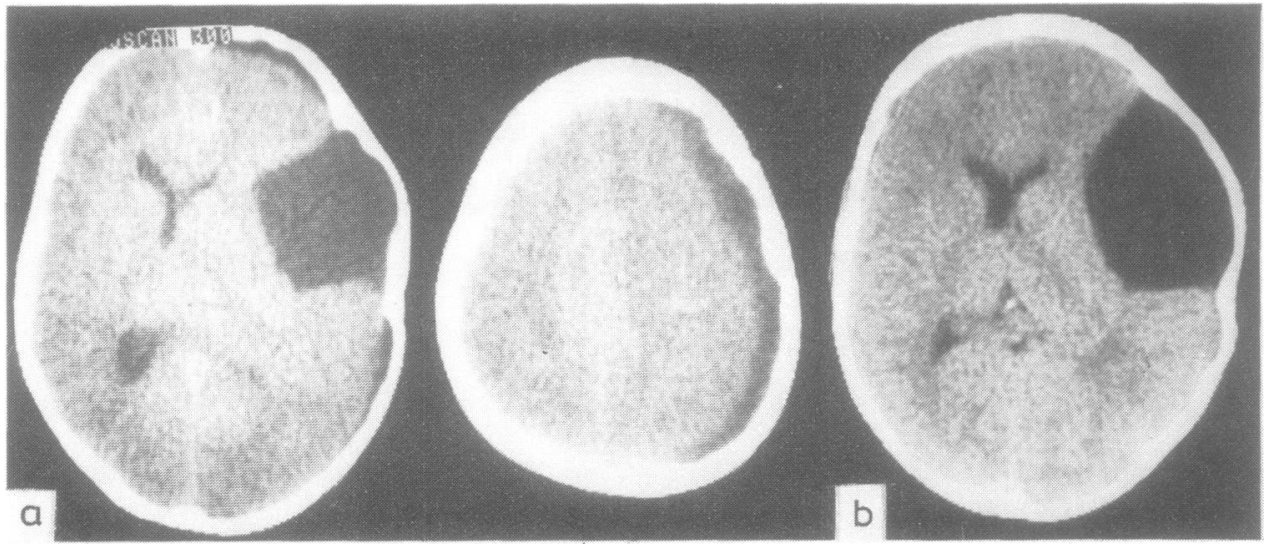

Fig 1 CT scan of patient 8: (a) preoperatively a left-sided cyst is present with a complicating subdural haematoma; (b) postoperatively no haematoma is visible; note that the cyst has re-expanded; the patient is, however free of symptoms.

symptom). In two patients the side of the cyst was consistent with focal characteristics of either the convulsion or the EEG. In the third patient (no 4) the focal epileptic signs were consistent with the EEG focus, but inconsistent with the side of the cyst; this was the only patient whose epilepsy did not improve as a result of operation; his chronic headache, however, disappeared.

\section{CT SCAN MEASUREMENTS}

The case of patient no 8 makes it clear that the cyst was formed by a space-occupying lesion rather than agenesis of the temporal lobe. The large cyst became symptomatic because of a complicating subdural haematoma following minor trauma (fig 1a): 18 months after the operation a large cyst was still present (fig 1b). It is evident, however, that the loss of brain space had been compensated for. The computer-aided volume measurements were as follows: cyst: $182 \mathrm{ml}$; both left and right supratentorial brain volume: $530 \mathrm{ml}$. Hence, there was no

Table 2 Cyst and brain volume of the affected side expressed as the percentage of the brain volume on the normal side

\begin{tabular}{llc}
\hline Pt. No. & $\begin{array}{l}\text { Brain volume } \\
\text { affected side (\%) }\end{array}$ & Cyst volume (\%) \\
\hline 1 & not measured & $<1$ \\
2 & 97 & 2 \\
3 & 106 & 3 \\
4 & 106 & 5 \\
5 & 102 & 6 \\
6 & 105 & 12 \\
7 & 103 & 5 \\
8 & 97 & 32 \\
9 & 98 & 21 \\
10 & 99 & 10 \\
\hline
\end{tabular}

loss of brain tissue. The volume measurements made by hand are summarised in table 2 ; the cyst volumes and the brain volumes on the affected side were related to the normal side. Irrespective of the size of the cyst, the brain volumes on both sides were approximately equal, the mean value on the affected side being $101.4 \pm 3.8 \%$. This is not significantly different from the normal side (Student's $t$ test for paired observations).

The results of the indirect method, measuring the skull "radius" on both sides at the level of the pineal gland, are presented in fig 2 . The difference between the affected and the normal side is proportionally larger in skulls with larger cysts.

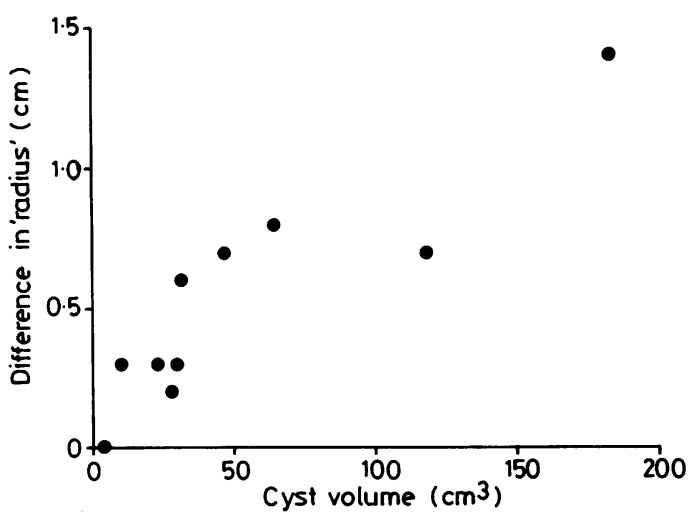

Fig 2 Relationship between volume of cyst and difference in 'radius' between the affected and the normal side. 
DEXTERITY AND PSYCHOLOGICAL

FUNCTIONING

Considering temporal lobe agenesis as a possibility, we looked for signs of functional impairment. The intellectual function in all patients but patient no 5 was average or even above average with regard to educational or occupational level. For instance, the girl with the largest cyst (fig 1) had excellent school results and was socially fully integrated. Patient no 5 differs from the others in that he was born with a skull circumference in excess of the 98 th percentile; this indicates growth of the cyst before birth. He presented with headache during walking, but other complaints were delayed development of speech and enuresis. After the operation a considerable cyst still existed $(29 \mathrm{ml})$. Despite this, his development following operation had, according to his parents, accelerated to near-normal level.

Seven of the cysts were located on the left side. Five of these patients, including those with the largest cysts, were nevertheless right-handed.

\section{Discussion}

Developmental cysts in the middle cranial fossa are sometimes considered to be primary arachnoid malformations, ${ }^{19-22}$ but more often they are believed to be secondary fluid collections ${ }^{139-12} 2.3$ in the absence of a part of the temporal lobe. Absence of brain tissue should lead to a difference in brain volume between the two sides. Volume measurements of the CT scans of these ten patients, however, led to the opposite conclusion: there was no loss of brain tissue, not even when the cysts were very large (table 2). In addition, it could be demonstrated that the affected hemicranium was larger, the increase being proportional to the size of the cyst, and therefore able to harbour both the cyst and the normal brain volume (fig 2 ). Shaw ${ }^{24}$ demonstrated the same phenomenon in a postmortem study of two brains with temporal cysts; he could not detect any left/right difference in brain volume or weight. It can, therefore, be concluded that there was no loss of brain tissue. Consequently the cyst has to be the primary developmental disorder with secondary displacement of the brain. This conclusion also explains why, in the great majority of cases, no motor deficit, not even a shift of handedness, and no intellectual loss has been found in this series or in others. $^{34}$

Progressive symptoms suggestive of increased CSF pressure or brain shift are caused by a decompensation of the intracranial contents, usually by subdural or intracystic bleeding. This complication occurs most frequently before the age of $20 .^{+}$Four such patients are included in this series (numbers $6,7,8$,
9). The surgical therapy consists of releasing the haematoma and removing the cyst. The results were excellent and comparable to those in the literature listed in table 3; only the series that specified their results according to complaints have been included here.

Non-progressive symptoms such as headache or epilepsy can occur with cysts uncomplicated by bleeding. Sometimes this is attributed to expansion of the cyst; a valve mechanism ${ }^{25}$ or active secretion ${ }^{19}$ has been suggested. An indirect argument for expansion could be a large rounded cyst showing signs of compression on the CT scan. ${ }^{22}$ Patients 4 and 5 fulfil this radiological criterion. If expansion occurs before birth, it should result in skull enlargement, possibly with some brain damage (patient 5). Aicardi and Bauman, ${ }^{1}$ however, reported macrocrania of a severe degree without any neurological signs or abnormalities in development, in accordance with the conclusion that there is no loss of tissue.

More often non-progressive symptoms are found in patients with angular cysts without signs of expansion (patients 1-3). The cause of this has not yet been clarified. It has, however, been known for some time that many cysts are in fact diverticula. Surgery has revealed an opening to the basal cisterns $^{4}{ }^{12} 23$ and on cisternography the cyst can be shown to fill with air, ${ }^{26}$ isotope $^{1327}$ or metrizamide..$^{314} 28$ In these instances increased intracystic pressure is unlikely to play a role. Nevertheless, operation has been reported to cause relief of headache in three patients with diverticula. ${ }^{12-14}$ An explanation other than intracystic pressure could be a local change in the functions of the subarachnoidal space: (1) Disturbance of the mechanical buffer for brain movement based on a smooth redistribution of CSF and fine trabeculation within the subarachnoid space is certainly present and could lead to abnormal traction and compression. (2) Obliteration of the temporal subarachnoid

Table 3 Result of operation in patients with progressive symptoms caused by haemorrhage

\begin{tabular}{|c|c|c|c|}
\hline Authors & $\begin{array}{l}\text { No. of } \\
\text { patients }\end{array}$ & $\begin{array}{l}\text { No. of } \\
\text { bleedings }\end{array}$ & Result \\
\hline $\begin{array}{l}\text { Aicardi and } \\
\text { Bauman, } 1975^{5}\end{array}$ & 2 & 2 & $\begin{array}{l}1 \text { good } \\
1 \text { sudden death }\end{array}$ \\
\hline $\begin{array}{l}\text { Smith and } \\
\text { Smith, } 1976^{6}\end{array}$ & 1 & 1 & good \\
\hline $\begin{array}{l}\text { Leo et al, } 1979^{7} \\
\text { Heimans et al, }\end{array}$ & 1 & 0 & improved \\
\hline $\begin{array}{l}1979^{8} \\
\text { Galassi et al, }\end{array}$ & 2 & 0 & good \\
\hline $\begin{array}{l}1980^{3} \\
\text { Auer et al, } 1981^{9} \\
\text { Varma et al, } 1981^{10} \\
\text { This series }\end{array}$ & $\begin{array}{r}12 \\
5 \\
6 \\
4\end{array}$ & $\begin{array}{l}7 \\
5 \\
6 \\
4\end{array}$ & $\begin{array}{l}\text { good } \\
\text { good } \\
\text { good } \\
\text { good }\end{array}$ \\
\hline
\end{tabular}


Table 4 Result of operation in patients with non-progressive symptoms: headache

\begin{tabular}{|c|c|c|c|}
\hline Authors & $\begin{array}{l}\text { No. of } \\
\text { patients }\end{array}$ & Result & $\begin{array}{l}\text { Duration } \\
\text { follow-up }\end{array}$ \\
\hline \multicolumn{4}{|l|}{ Tiberin and } \\
\hline Gruszkiewicz, $1961^{11}$ & 1 & good & 9 months \\
\hline \multicolumn{4}{|l|}{ Törmä and } \\
\hline Heiskanen, $1962^{12}$ & 2 & good & 1 and 7 years \\
\hline Seur and Kooman, $1976^{13}$ & 1 & good & \\
\hline Smith and Smith, $1976^{6}$ & 1 & good & 3 years \\
\hline Handa et al, $1977^{14}$ & 1 & good & \\
\hline $\begin{array}{l}\text { Anderson et al, } \\
1979^{15}\end{array}$ & 6 & $\begin{array}{l}\text { "good } \\
\text { results" }\end{array}$ & $\begin{array}{l}8 \text { months- } \\
18 \text { years }\end{array}$ \\
\hline Leo et al, $1979^{7}$ & 1 & "improved" & $?$ \\
\hline This series & 4 & $\begin{array}{l}3 \text { good } \\
1 \text { unchanged }\end{array}$ & $6-54$ months \\
\hline
\end{tabular}

space could also block the lateral CSF route to the site of absorption with intermittent rises in CSF pressure as has been found with solid tumours. ${ }^{29} \mathrm{Kato}$ et $a l^{26}$ indeed found blockage of the lateral route in two patients, and Stein ${ }^{27}$ even described an infant with a diverticulum associated with communicating hydrocephalus.

The post-operative results of both groups, angular cysts and round "expanding" cysts have been combined. Three of four patients who suffered from chronic headache were cured. The one patient who did not benefit from operation suffered from localised headache over the cyst, but sometimes identical pain on the other side. Two years after the operation an open connection between the cyst and the basal cisterns was demonstrated. In this case, it is possible that the headaches were not related to the cyst.

Two of three patients with epilepsy benefited from operation. The third had an epileptic focus on the opposite side from the cyst. The epilepsy did not improve but his chronic headache disappeared after the operation.

Previous studies have also shown that chronic headache and epilepsy can be improved or cured by operation (tables 3 and 4). One may argue that only positive results are published. The original authors, however, selected the patients in these tables not on the basis of non-progressive symptoms, but solely on the existence of a cyst, irrespective of the presenting complaint. Therefore, the high rate of postoperative improvement suggested by the tables is probably valid. Further confirmation comes from our patients 6,7 and 9 . They all had secondary haemorrhage after minor trauma. In retrospect, they also had chronic complaints. In all three, these disappeared after some time. Non-progressive symptoms have therefore a good prognosis after operation.

Two different surgical approaches have been advocated: removing the outer membrane and opening the inner membrane giving drainage to the basal cisterns $36810121530-34$ and cystocardial or cystoperitoneal drainage. ${ }^{26}{ }^{35}{ }^{36}$ Since intracystic pressure is not necessarily related to the symptoms, pressure regulation with drainage of the cyst does not seem to be a logical first choice. Restoration of CSF dynamics by removing the membranes should be effective in all cases. Furthermore, the effectiveness of different operations should not be judged by the disappearance of the cyst on the CT scan. Because of the early developmental displacement of the brain, one should expect a residual cyst after surgery. This is clearly demonstrated in figures $1 \mathrm{a}$ and $\mathrm{b}$ : after removal of the subdural haematoma the cyst even reexpanded, while the patient became symptom-free.

To summarise, the course of events may be as follows: During development, a cystic arachnoid malformation displaces the temporal lobe without any functional loss. Symptoms, if any, are caused (1) by secondary haemorrhage, (2) by expansion of the cyst, or (3) by disturbed CSF dynamics without increasing intracystic pressure. Surgery should aim to evacuate the mass and restore the CSF dynamics; postoperatively, a residual cyst can be expected.

We thank G Blaauw, $J$ van Dongen and $J$ van Gijn for their valuable comments, Mrs J Doornbosch for secretarial help and Mrs BS Vollers-King for language editing of the text.

Table 5 Result of operation in patients with non-progressive symptoms: epilepsy

\begin{tabular}{|c|c|c|c|c|}
\hline Authors & No. of patients & Result & Medication & Duration follow-up \\
\hline $\begin{array}{l}\text { Roger et al, 1964 } \\
\text { Vigouroux et al, } 1966^{17} \\
\text { Bhandari, 1972 } \\
\text { Aicardi \& Bauman, } 1975^{5} \\
\text { Smith \& Smith, 1976 } \\
\text { Heimans et al, } 1979^{8} \\
\text { Galassie et al, 1980 } \\
\text { Auer et al, 19819 } \\
\text { This series }\end{array}$ & $\begin{array}{l}1 \\
2 \\
1 \\
1 \\
1 \\
1 \\
5 \\
3 \\
3\end{array}$ & $\begin{array}{l}\text { good } \\
\text { good } \\
\text { good } \\
\text { good } \\
\text { good } \\
\text { improved } \\
\text { improved } \\
\text { good } \\
\text { no change } \\
\text { improved } \\
\text { good }\end{array}$ & $\begin{array}{l}? \\
? \\
? \\
? \\
+ \\
+ \\
+ \\
+ \\
+ \\
+\end{array}$ & $\begin{array}{l}? ? \\
? \\
? \\
5 \text { years } \\
5 \text { years } \\
? \\
6 \text { months-9 years } \\
1-3 \text { years } \\
4 \frac{1}{2} \text { years } \\
9 \text { months } \\
6 \text { months }\end{array}$ \\
\hline
\end{tabular}

good = free from fits

improved = significant reduction of fits 


\section{References}

${ }^{1}$ Robinson RG. The temporal lobe agenesis syndrome. Brain 1964;88:87-106.

2 Shaw CM, Alvord Jr. EC. "Congenital Arachnoid" Cysts and their differential diagnosis. In: Vinken PJ and Bruyn GW, eds. Handbook of Clinical Neurology, Vol. 31, 1977;75-136.

${ }^{3}$ Galassi E, Piazza G, Gaist G, Frank F. Arachnoid cysts of the middle cranial fossa: a clinical and radiological study of 25 cases treated surgically. Surg Neurol 1980;14:211-19.

${ }^{4}$ Robinson RG. Congenital cysts of the brain: arachnoid malformations. Prog Neurol Surg 1971;4:133-74.

${ }^{5}$ Aicardi J, Bauman F. Supratentorial extracerebral cysts in infants and children. $J$ Neurol Neurosurg Psychiatry 1975;38:57-68.

${ }^{6}$ Smith RA, Smit WA. Arachnoid cysts of the middle cranial fossa. Surg Neurol 1976;5:246-52.

${ }^{7}$ Leo JS, Pinto RS, Hulvat GF, Epstein F, Kricheff JJ. Computed tomography of arachnoid cysts. Radiology 1979;130:675-80.

${ }^{8}$ Heimans JJ, Duinen MThA van, Drift JHA van der. Arachnoid cysts in the middle cranial fossa. Clin Neurol Neurosurg 1979; 81:291-300.

${ }^{9}$ Auer LM, Gallhofer B, Ladurner G, Sager WD, Heppner F, Lechner H. Diagnosis and treatment of middle fossa arachnoid cysts and subdural haematomas. $J$ Neurosurg 1981;54:366-9.

${ }^{10}$ Varma TRK, Sedzimir LB, Miles JB. Posttraumatic complications of arachnoid cysts and temporal lobe agenesis. J Neurol Neurosurg Psychiatry 1981;44:2934.

${ }^{11}$ Tiberin P, Gruszkiewicz J. Chronic arachnoidal cysts of the middle cranial fossa and their relation to trauma. $J$ Neurol Neurosurg Psychiatry 1961;24:86-91.

12 Törmä T, Heiskanen $\mathrm{O}$. Chronic subarachnoidal cysts in the middle cranial fossa. Acta Neurol Scand 1962;38: $166-70$.

13. Seur NH, Kooman A. Arachnoid cysts of the middle fossa with paradoxical changes of bony structures. Neuroradiology 1976;12:177-83.

${ }^{14}$ Handa J, Nakano Y, Aii H. Cisternography with intracranial arachnoidal cysts. Surg Neurol 1977;8:451-54.

1s Anderson FM, Segall HD, Caton WL. Use of computerized tomography scanning in supratentorial arachnoid cysts, a report on 20 children and four adults. $J$ Neurosurg 1979;50:333-8.

${ }^{16}$ Roger J, Salamon G, Soulayrol R, Combalbert A, Regis H. Les collections sous durale chroniques de l'enfant épileptique (hydrome et kystes arachnoidiens). Neurochirurgie 1964;10:186-95.

${ }^{17}$ Vigouroux RP, Choux M, Baurand C. Les kystes arachnoidiens congenitaux. Neurochirurgia 1966; 9:169-87.

${ }^{18}$ Bhandari YS. Non-communicating supratentorial sub- arachnoid cysts. J Neurol Neurosurg Psychiatry 1972;35:763-70.

${ }^{19}$ Go KG, Houthoff HJ, Blaauw EH, Stokroos I, Blaauw G. Morphology and origin of arachnoid cysts, scanning and transmission electron microscopy of three cases. Acta Neuropathol 1978;44:57-62.

${ }^{20}$ Rengachary SS, Watanabe I. Ultrastructure and pathogenesis of intracranial arachnoid cysts. J Neuropathol Exp Neurol 1981;40:61-83.

${ }^{21}$ Rengachary SS, Watanabe I, Brackett ChE. Pathogenesis of intracranial arachnoid cysts. Surg Neurol 1978;9:139-44.

${ }^{22}$ Giudicelli G, Hassoun J, Choux M, Tonon C. Supratentorial "Arachnoid" Cysts. J Neuroradiol 1982;9:179-201.

${ }^{23}$ Robinson RG. Intracranial collections of fluid with local bulging of the skull. $J$ Neurosurg 1955;12:345-52.

${ }^{24}$ Shaw CM. "Arachnoid cysts" of the Sylvian fissure versus "temporal lobe agenesis" syndrome. Ann Neurol 1979;5:483-5.

${ }^{25}$ Al-Din AN, Williams B. A case of high-pressure intracerebral pouch. J Neurol Neurosurg Psychiatry 1981;44:918-23.

${ }^{26}$ Kato M, Nakada Y, Ariga N, Kokubo Y, Makino $H$. Prognosis of four cases of primary middle fossa arachnoid cysts in children. Childs Brain 1980;7:195204.

${ }^{27}$ Stein SC. Intracranial developmental cysts in children: treatment by cystoperitoneal shunting. Neurosurgery 1981;8:647-50.

${ }^{28}$ Ruscalleda J, Guardia E, Santos FM dos, Carvajal A. Dynamic study of arachnoid cysts with metrizamide. Neuroradiology 1980;20:185-9.

${ }^{29} \mathrm{Crevel} \mathrm{H}$ van. Papilloedema, CSF pressure, and CSF flow in cerebral tumours. J Neurol Neurosurg Psychiatry 1979;42:493-500.

${ }^{30}$ Choux M, Raybaurd Ch, Pinsard N, Hassoun J, Gambarelli D. Intracranial supratentorial cysts in children excluding tumor and parasytic cysts. Childs Brain 1978;4:15-32.

${ }^{31}$ Clavel M. Middle fossa arachnoid cysts. J Neurosurg 1981;55:853.

${ }^{32}$ Dyck P, Gruskin Ph. Supratentorial arachnoid cysts in adults. Arch Neurol 1977;34:276-9.

${ }^{33}$ McCullough DC, Harbert JC, Manz J. Large arachnoid cysts at the cranial base. Neurosurgery 1980;6:76-81.

${ }^{34}$ Milhorat ThH. Pediatric neurosurgery, chapter 7: benign intracranial cysts, pp. 191-209. Contemporary Neurology vol 16, Philadelphia: FA Davis Company, 1978.

${ }^{35}$ Geissinger JD, Kohler WC, Robinson BW, Davis FM. Arachnoid cysts of the middle cranial fossa: surgical considerations. Surg Neurol 1978;10:27-33.

${ }^{36}$ Sprung Ch, Mauersberger W. Value of computed tomography for the diagnosis of arachnoid cysts and assessment of surgical treatment. Acta Neurochir Suppl 1979;28:619-26. 